\title{
Reduction of COD and Color of Acid and Reactive Dyestuff Wastewater Using Ozone
}

\author{
Jae-Wook Choi, Hyung Keun Song, Whun Lee*, Kee-Kahb Koo*, Choon Han** and Byung-Ki Na***,† \\ Clean Technology Center, Korea Institute of Science and Technology, P.O.Box 131, Cheongryang, Seoul 130-650, Korea \\ *Dept. of Chem. Eng., Sogang Univ., 1 Sinsudong, Mapo, Seoul 121-742, Korea \\ **Dept. of Chem. Eng., Kwangwoon Univ., Wolgyedong, Nowonku, Seoul 139-701, Korea \\ ***School of Chem. Eng., Chungbuk National Univ., San 48 Gaesindong, Cheongju, Chungbuk 361-763, Korea \\ (Received 11 April $2003 \cdot$ accepted 6 October 2003)
}

\begin{abstract}
Wastewaters obtained from bromamine acid dye and reactive dye manufacturing were treated by ozone bubbling in a cylindrical batch reactor for the purpose of reducing COD to below $150 \mathrm{mg} / \mathrm{L}$, which is the environmental discharge standard of the Republic of Korea. Remarkable COD reduction and decolorization were observed at $\mathrm{pH}$ over 11. High inlet gas flowrate and high concentration of ozone gave better results. Little precipitation was observed under the conditions of remarkable COD reduction. At $\mathrm{pH}$ of 11, $15 \mathrm{LPM}$ of inlet gas flowrate and $89.3 \mathrm{~g} / \mathrm{Nm}^{3}$ of ozone flowrate, the COD of bromamine acid dyestuff wastewater was reduced to $95 \mathrm{mg} / \mathrm{L}$ after 90 minutes, and the COD of reactive dyestuff wastewater was reduced to $120 \mathrm{mg} / \mathrm{L}$ after 120 minutes. Decolorization was completed after 30 minutes of reaction.
\end{abstract}

Key words: Ozone, Dyestuff, Wastewater, Color, COD, pH

\section{INTRODUCTION}

A great deal of water is used in the dyestuff manufacturing process. Dyestuff is formulated from many kinds of chemicals, and excess chemicals are discharged as wastewater during the process. Sometimes products are discharged into the wastewater during the process of salting-out. Therefore, $15 \%$ of total amounts are lost as wastewater [Salem, 2000]. Dyestuff wastewater has a COD of 3,000$2,0000 \mathrm{mg} / \mathrm{L}$. Not only is it directly toxic to the biological world, but it also has a dark color, which blocks sun light. By these reasons, it causes many problems to the ecosystem. However, it is very difficult to decolorize with traditional physical and chemical methods [Kuo, 1992; Kong et al., 2003]. Dyestuff wastewater is composed of many organic compounds that are difficult to treat by biological methods [Bigda, 1995; Sarasa et al., 1998]. Effective methods of decreasing COD and color are chosen depending on the type of dyestuff, and multiple processes are generally used to successfully treat the wastewater [Kuo, 1992; Li et al., 1999].

To date, coagulation methods [Han et al., 1999; Orta et al., 1998], biological methods [Kang et al., 2000; Li et al., 1999; Tatarko et al., 1998; Weber et al., 1999; Lee and Hano, 2001], adsorption methods [Cooney, 1999; Lee et al., 1997; Markovska et al., 2001; Weber et al., 1999; Hur and Kim, 2000], chemical methods [Kang et al., 2000; Kuo, 1992; Park et al., 1999; Salem et al., 2000; Weber et al., 1999] and membrane separation methods [Weber et al., 1999] have been used to treat dyestuff wastewater. Coagulation is effective for treatment of insoluble dyestuff wastewater but not so effective for soluble dyestuff wastewater [Kang et al., 2000; Kuo, 1992]. The biological method has difficulty finding the proper micro-organisms which can withstand toxicity of the dyestuff wastewater [Ince, 1999; Kang et al., 2000; Kuo, 1992; Weber et al., 1999]. The adsorp-

†T whom correspondence should be addressed.

E-mail: nabk@chungbuk.ac.kr tion method has difficulties in the treatment of insoluble dyestuff wastewater and it is very difficult to find the desorption process [Kuo, 1992; Kim et al., 2002]. The membrane separation method has problems in that the pore is filled with the particles, so the membrane lifetime is very short [Weber et al., 1999]. The chemical method is to oxidize organic materials by oxidizing agents. Fenton's method is the representative chemical method that uses $\mathrm{H}_{2} \mathrm{O}_{2}$ and iron catalysts. Most factories use this method to reduce $\mathrm{COD}$ and color. But, it cannot satisfy the environmental discharge standard by itself alone and the cost is relatively high. The evaporation method is the most ideal method ever developed, but it has high operating cost.

An ozone method is one of the chemical methods, and it is used as an oxidizing agent instead of $\mathrm{H}_{2} \mathrm{O}_{2}$. The ozone method is known to be effective for decomposing organic chemicals containing carbon-carbon double bonds, olefinic double bonds, acetylenic triple bonds, aromatic compounds, phenols, polycyclic aromatics, heterocyclics, carbon-nitrogen double bonds, carbon-hydrogen bonds, silicon-hydrogen and carbon-metal bonds [Evans, 1975]. Most of the dyestuffs are composed of aromatic organic compounds, so the ozone method is getting attention with the prediction that it could decompose various kinds of dyestuffs. It is reported that the ozone is effective for reducing the color of dyestuff wastewater, but it is not so effective for the COD reduction [Churchley, 1998; Kuo, 1992; Sarasa et al., 1998]. Therefore, most studies for dyestuff wastewater treatment with ozone have been interested in decolorization rather than COD reduction. It has been emphasized that the ozone works as a catalyst for the physical and chemical treatment [Orta et al., 1998].

This aim of this study was to show that the ozone method is effective for the reduction of COD as well as decolorization of dyestuff wastewater, to present the optimum conditions for dyestuff wastewater treatment and to present the design parameters for scaleup. COD reduction of dyestuff wastewater below $150 \mathrm{mg} / \mathrm{L}$, which is the environmental discharge standard of the Republic Korea, was 
the object of this study. Raw dyestuff wastewaters obtained from the Daekwang Chemical Co. at Namdong industry complex in Inchon were used for the experiments. The wastewater was treated by bubbling ozone in the cylindrical type batch reactor. The COD, color and $\mathrm{pH}$ of sample were analyzed, taking the concentration of ozone, the flowrate of inlet gas and the $\mathrm{pH}$ of sample as variables.

\section{EXPERIMENTS}

Wastewater contains various kinds of dyestuff, and it is difficult to identify the components precisely. The major components could be determined by investigating the major dyestuffs. Bromamine acid dyestuff wastewater and reactive dyestuff wastewater were used in this experiment. These dyestuffs have relatively high solubility according to the low molecular weight. Insoluble components can be removed easily by a physical method such as the coagulation process. In the case of raw acid dyestuff wastewater, the COD was $3,240 \mathrm{mg} / \mathrm{L}$, $\mathrm{pH}$ was 3.7, and maximum absorbance was 11.1 at the wavelength $442 \mathrm{~nm}$. In the case of raw reactive dyestuff wastewater, the COD was $2,560 \mathrm{mg} / \mathrm{L}$, $\mathrm{pH}$ was 4.1 , and maximum absorbance was 6.3 at the wavelength of $400 \mathrm{~nm}$. $45 \% \mathrm{NaOH}$ solution was used to adjust the $\mathrm{pH}$ of samples.

Oxygen of $99.7 \%$ purity was used to generate ozone. Ozone was generated by flowing the oxygen into the ozone generator (Ilssan, $3 \mathrm{E} 3 \mathrm{G}$ ozone generator). Ozone concentrations at different $\mathrm{O}_{2}$ flowrates are listed in Table 1, and ozone concentrations at different output voltages are listed in Table 2. Ozone was contacted with the dyestuff wastewater in the cylindrical type batch reactor (length: $1,000 \mathrm{~mm}$, I.D.: $60 \mathrm{~mm}$ ) by bubbling. The reactor was made of acryl to keep away from the oxidation and to observe the change of the color easily. A ceramic air distributor (O.D.: $40 \mathrm{~mm}$ ) was located at the bottom of the cylinder and the ozone bubble was generated from the distributor. The experimental set-up is shown in Fig. 1.

The $\mathrm{pH}$, absorbance and COD of dyestuff wastewater were measured after filtration. The $\mathrm{pH}$ was measured with a $\mathrm{pH}$ meter (Orion 410A), and the absorbance was measured with a UV/VIS spectrophotometer (Beckman DU-650). The potassium permanganate method was used to measure the COD because the environmental discharge standard of the Republic of Korea prescribes it. COD of dye-

Table 1. Characteristics of ozone concentration according to the $\mathrm{O}_{2}$ flow rate (output voltage: $12 \mathrm{kV}$ )

\begin{tabular}{ccc}
\hline \hline $\mathrm{O}_{2}$ flow rate $(\mathrm{LPM})$ & $\mathrm{O}_{3}$ concentration $\left(\mathrm{g} / \mathrm{Nm}^{3}\right)$ & $\mathrm{O}_{3}$ amount $(\mathrm{g} / \mathrm{hr})$ \\
\hline 10.0 & 102.2 & 61.3 \\
12.5 & 96.0 & 72.0 \\
15 & 82.7 & 74.4 \\
\hline
\end{tabular}

Table 2. Characteristics of ozone concentration according to the output voltage (feed flowrate: 15 LPM)

\begin{tabular}{ccc}
\hline \hline Output voltage $(\mathrm{kV})$ & $\mathrm{O}_{3}$ concentration $\left(\mathrm{g} / \mathrm{Nm}^{3}\right)$ & $\mathrm{O}_{3}$ amount $(\mathrm{g} / \mathrm{hr})$ \\
\hline 9 & 54.0 & 48.6 \\
10 & 68.8 & 61.9 \\
11 & 76.5 & 68.9 \\
12 & 82.7 & 74.4 \\
\hline
\end{tabular}

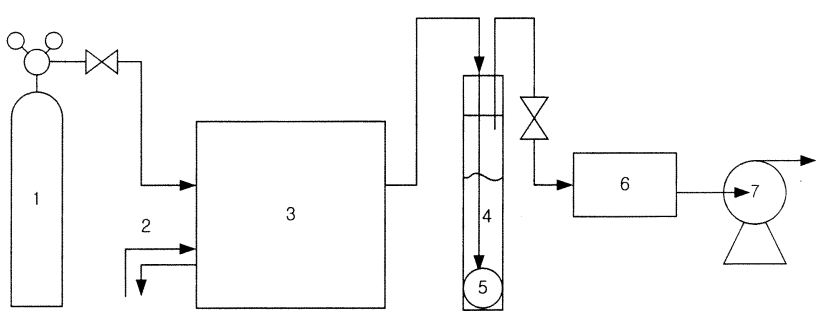

Fig. 1. Schematic diagram of experimental system for the treatment of dyestuff wastewater with ozone.
1. $\mathrm{O}_{2}$ cylinder
2. Cooling water
5. Gas disperser
3. Ozone generator
6. Ozone detector
4. Sample
7. Gas inspirator

stuff wastewater of high concentration was measured by basic potassium permanganate method because of the high quantity of chlorine ions in the sample. After the ozone treatment, COD was measured by acidic potassium permanganate method.

\section{RESULTS AND DISCUSSION}

\section{Effect of $\mathbf{p H}$ in Ozone Treatment}

The $\mathrm{pH}$ of raw acid dyestuff wastewater was 3.7 and that of raw reactive dyestuff wastewater was 4.1. The COD of acid dyestuff wastewater was reduced from $3,240 \mathrm{mg} / \mathrm{L}$ to $1,520 \mathrm{mg} / \mathrm{L}$ after ozone bubbling treatment for $2 \mathrm{hr}$. The COD of reactive dyestuff wastewater was reduced from $2,560 \mathrm{mg} / \mathrm{L}$ to $1,120 \mathrm{mg} / \mathrm{L}$ at the same condition. When the $\mathrm{pH}$ was changed to 7.0, the COD of acid dyestuff wastewater was reduced to $710 \mathrm{mg} / \mathrm{L}$ and that of reactive dyestuff wastewater was reduced to $986 \mathrm{mg} / \mathrm{L}$. With the idea that the difference of the results came from the difference of the $\mathrm{pH}$ of samples, ozone treatment experiments were performed with various $\mathrm{pH}$ of samples. The COD after ozone treatment was measured at

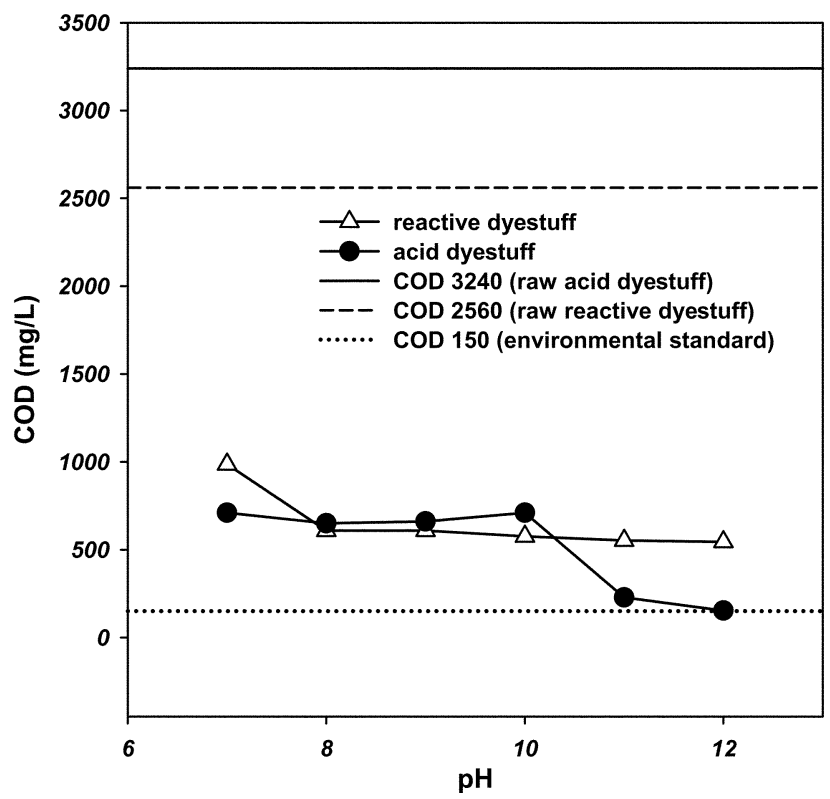

Fig. 2. The reduction of COD after ozone treatment according to the changes of $\mathrm{pH}$. 
the various $\mathrm{pH}$ of 7-12, and the results are shown in Fig. 2. Reaction time of $120 \mathrm{~min}$, sample volume of $500 \mathrm{ml}$, output voltage of $12 \mathrm{kV}$ and inlet gas flowrate of 12.5 LPM was fixed in this experiments.

In the case of reactive dyestuff wastewater, the COD decreased slightly with all $\mathrm{pH}$. With acid dyestuff wastewater, the COD decreased slightly at $\mathrm{pH} 7-10$, and it decreased greatly to $228 \mathrm{mg} / \mathrm{L}$ showing a reduction rate of $93 \%$ at $\mathrm{pH} 11$. The COD decreased to $153 \mathrm{mg} / \mathrm{L}$ at $\mathrm{pH} 12$ showing a reduction rate of $95 \%$.

Acid dyestuff wastewater was observed to be sensitive to $\mathrm{pH}$ variation. With the result of acid dyestuff wastewater, there was a possibility that the COD reduction would be effective at high $\mathrm{pH} .45$ $\mathrm{ml}$ of $45 \% \mathrm{NaOH}$ solution was needed to adjust $\mathrm{pH} 11$ with 30 liters of dyestuff wastewater. $70 \mathrm{ml}$ of $45 \% \mathrm{NaOH}$ solution was needed to adjust $\mathrm{pH} 12$. When the $\mathrm{pH}$ was changed from 11 to 12 , the reduction rate of COD was changed from $93 \%$ to $95 \%$. This meant that the increase of $\mathrm{NaOH}$ solution does not affect the COD so much. It was decided that the optimum $\mathrm{pH}$ would be 11 .

In Fenton's method $\mathrm{OH}$ radical acts as an oxidant. The $\mathrm{OH}$ radical appears to be active in the low $\mathrm{pH}$ conditions of 3-5. Therefore, low $\mathrm{pH}$ has been reported to be effective with Fentons method [Kang et al., 2000; Kuo, 1992; Park et al., 1999; Weber et al., 1999]. On the contrary, high $\mathrm{pH}$ has been reported to be effective with the ozone method [Sarasa et al., 1998]. In the ozone method, oxygen radicals and ozone molecules act as an oxidant. The ozone radical appears to be active at basic $\mathrm{pH}$ condition, and this is because of the $\mathrm{OH}^{-}$.

When the $\mathrm{pH}$ of sample was compared before and after the ozone treatment, the $\mathrm{pH}$ was reduced for all $\mathrm{pH}$ ranges as shown in Fig. 3. In the case of the reactive dyestuff, the $\mathrm{OH}^{-}$changes to $\mathrm{OH}$ radical and effectively is used to react with the dyestuff. A remarkable amount of precipitation was observed after the reaction with $\mathrm{pH}$ variation. In the case of acid dyestuff wastewater, a large quantity of brown precipitation was detected up to $\mathrm{pH} 10$, but little color-

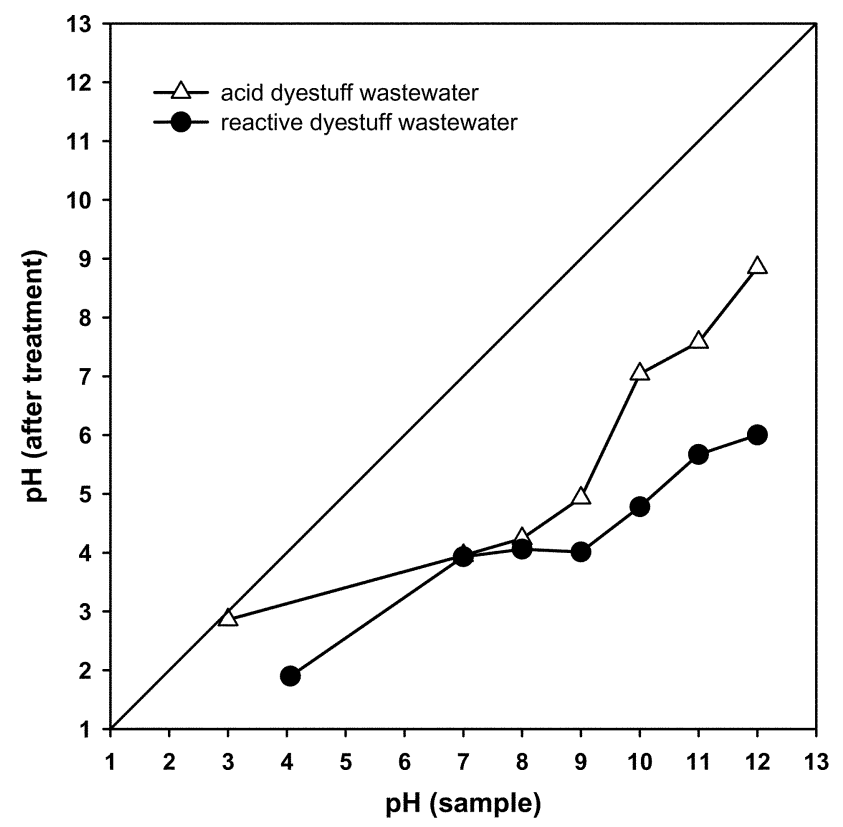

Fig. 3. The comparison of $\mathrm{pH}$ between the before-treatment and after-treatment samples with ozone. less precipitation was detected from $\mathrm{pH}$ 11. For reactive dyestuff wastewater, brown precipitation was detected under all conditions. In general, COD was reduced remarkably under the conditions showing little precipitation after reaction. It is reported that the production of precipitation during the wastewater treatment is helpful to the reduction of COD [Kuo, 1992].

Theoretically, if a complete reaction would be possible, organic compounds composing dyestuff wastewater completely decompose to $\mathrm{H}_{2} \mathrm{O}$ and $\mathrm{CO}_{2}$ [Bigda, 1995; Lang et al., 1998; Rinker et al., 1999]. However, complete decomposition is not so easy. Therefore, remaining compounds could be eliminated by precipitation. For Fenton's method, it is reported that ozone is helpful for dyestuff wastewater treatment by filtration after precipitation [Kuo, 1992]. It is also reported that ozone is helpful for deducing coherent material during the coagulation process. Ozone could make particle size large, so dyestuff water could be filtrated easily [Orta et al., 1998]. However, the results of this study for ozone method led to the opposite conclusion that the COD reduction was remarkable with little precipitation at $\mathrm{pH} 11$. Therefore, most of the organic compounds in dyestuff wastewater were supposed to be decomposed to $\mathrm{CO}_{2}$ and $\mathrm{H}_{2} \mathrm{O}$.

\section{Effect of Ozone Flowrate}

Experiments were performed at different oxygen flowrate under $\mathrm{pH}$ 11. Reaction time of $120 \mathrm{~min}$, sample volume of $500 \mathrm{ml}$, output voltage of $12 \mathrm{kV}$ and $\mathrm{pH}$ of 11 was fixed. Inlet gas flowrate was changed from 12.5 LPM to 15 LPM, and the results are shown in Fig. 4.

When the inlet gas flowrate was 12.5 LPM, the volume of bubble was 5 times larger than the volume of sample with the acid dyestuff wastewater, and it was 1.5 times with the reactive dyestuff wastewater. When the oxygen flow rate was 15 LPM, the volume of bubble was similar to the case of 12.5 LPM in the acid dyestuff wastewater, and it was 5 times with the reactive dyestuff wastewater. The bubbles settled down after $15 \mathrm{~min}$ of reaction. The COD of

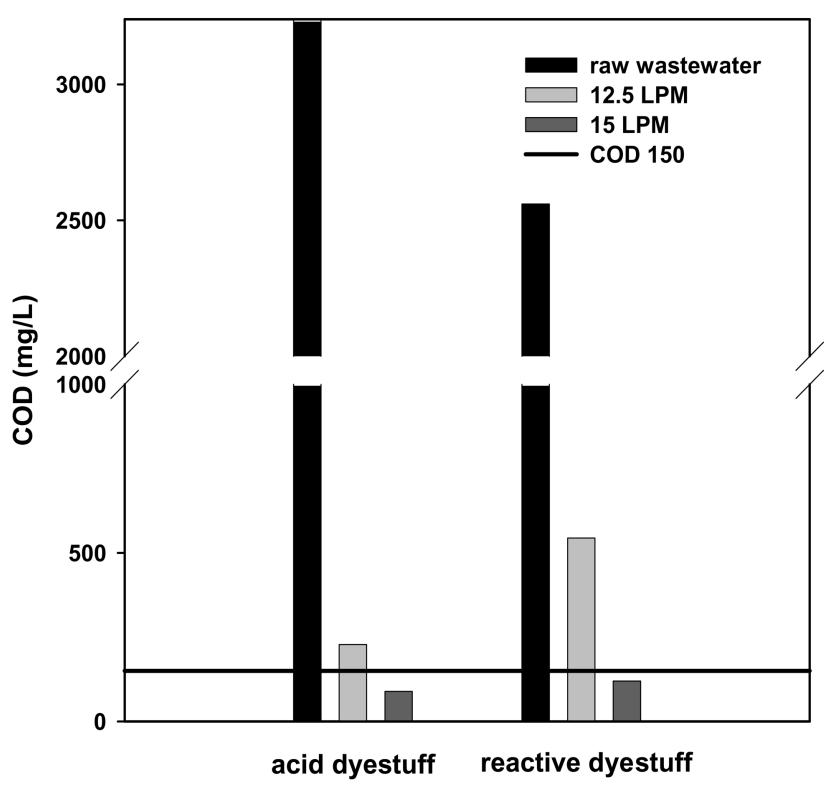

Fig. 4. The reduction of COD after the treatment depending on the $\mathrm{O}_{3}$ flowrate (LPM). 
acid dyestuff wastewater was reduced to $228 \mathrm{mg} / \mathrm{L}$, which was $93.0 \%$ reduction, at 12.5 LPM of inlet gas flowrate. It was reduced to 89 $\mathrm{mg} / \mathrm{L}$, which was $97.3 \%$ reduction, at $15 \mathrm{LPM}$. The COD of the reactive dyestuff wastewater reduced to $544 \mathrm{mg} / \mathrm{L}$, which was $78.8 \%$ reduction at $12.5 \mathrm{LPM}$. It was reduced to $120 \mathrm{mg} / \mathrm{L}$, which was 95.3\% reduction, at 15 LPM. The COD of the acid dyestuff wastewater reduced better than that of the reactive wastewater. The difference was large at 12.5 LPM of inlet gas flowrate. The COD of both samples reduced to below $150 \mathrm{mg} / \mathrm{L}$, which is the environmental discharge standard of the Republic of Korea. The COD was reduced remarkably at high concentration of ozone.

With the acid dyestuff wastewater, little precipitation was detected at 12.5 LPM and 15 LPM of inlet gas flowrate. With the reactive dyestuff wastewater, little precipitation was detected at 15 LPM, but brown precipitation was detected at 12.5 LPM.

The $\mathrm{pH}$ of the acid dyestuff wastewater was adjusted to 11 at the beginning of the experiment, and it changed to 7.6 at $12.5 \mathrm{LPM}$ and to 7.1 at $15 \mathrm{LPM}$. The $\mathrm{pH}$ of reactive dyestuff wastewater changed to 5.7 at $12.5 \mathrm{LPM}$ and to 4.6 at $15 \mathrm{LPM}$.

\section{Effect of Ozone Concentration}

An experiment was carried out under various ozone concentrations of $54.0-82.7 \mathrm{~g} / \mathrm{Nm}^{3}$. The working volume was $500 \mathrm{ml}, \mathrm{pH}$ was 11 , and inlet gas flowrate was 15 LPM. Reaction time was adjusted from 120 to $184 \mathrm{~min}$ at different ozone concentrations to make 149 $\mathrm{g}$ of total ozone.

The results are shown in Fig. 5. The COD of the acid dyestuff wastewater was reduced to $700 \mathrm{mg} / \mathrm{L}$ at $9 \mathrm{kV}$ of output voltage and $54.0 \mathrm{~g} / \mathrm{Nm}^{3}$ of ozone concentration. It was reduced to $89 \mathrm{mg} / \mathrm{L}$ at $12 \mathrm{kV}$ and $82.7 \mathrm{~g} / \mathrm{Nm}^{3}$.

The COD of reactive dyestuff wastewater was reduced to 746 $\mathrm{mg} / \mathrm{L}$ at $9 \mathrm{kV}$ of output voltage and $54.0 \mathrm{~g} / \mathrm{Nm}^{3}$ of ozone concentration. It was reduced to $120 \mathrm{mg} / \mathrm{L}$ at $12 \mathrm{kV}$ and $82.7 \mathrm{~g} / \mathrm{Nm}^{3}$. The results showed that a high ozone concentration with the same total amount of ozone gave a high COD reduction rate.

Brown precipitation was detected at 9 and $10 \mathrm{kV}$, and negligible

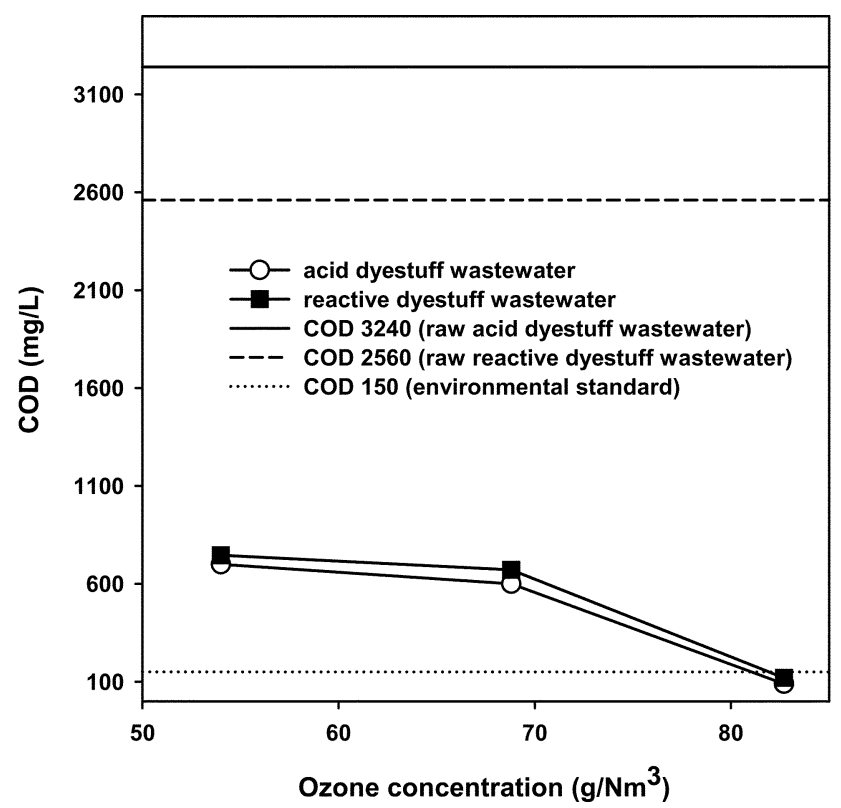

Fig. 5. The effect of ozone concentration on the reduction of COD.

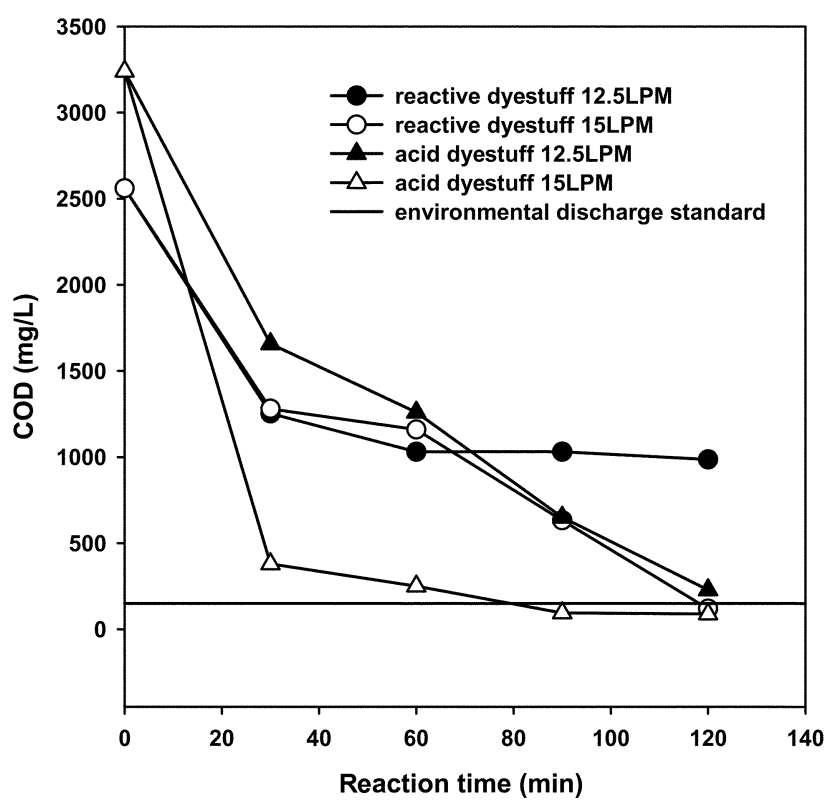

Fig. 6. The time-on stream of the COD reduction during the ozone treatment.

amount of precipitation was detected at $12 \mathrm{kV}$. The $\mathrm{pH}$ of the acid dyestuff wastewater shifted to 7.6 at $12 \mathrm{kV}$. The $\mathrm{pH}$ of the reactive dyestuff wastewater shifted to 4.6 at $12 \mathrm{kV}$.

\section{Effect of Reaction Time}

According to previous experiments, high $\mathrm{pH}$, high inlet gas flowrate and high ozone concentration were required for the effective treatment of the dyestuff wastewater by ozone. To find the optimum reaction time, experiments were performed with an inlet gas flowrate of 12.5 LPM and 15 LPM and the reaction time was 120 $\min$. The sample volume of $500 \mathrm{ml}$, output voltage of $12 \mathrm{kV}$ and $\mathrm{pH}$ of 11 were fixed. The results are shown in Fig. 6.

The COD reduction was remarkable at $15 \mathrm{LPM}$ of inlet gas flowrate compared to 12.5 LPM. Treatment of the acid dyestuff wastewater with Fenton's method reduced the COD to $400 \mathrm{mg} / \mathrm{L}$. Ozone treatment with 15 LPM for 30 min gave better result than Fenton's method. The COD of the acid dyestuff wastewater reduced to 95 $\mathrm{mg} / \mathrm{L}$ after $90 \mathrm{~min}$. The COD of the reactive dyestuff wastewater reduced to $120 \mathrm{mg} / \mathrm{L}$ after $120 \mathrm{~min}$. The optimum reaction times to meet the environmental discharge standard were $90 \mathrm{~min}$ for the acid dyestuff wastewater and $120 \mathrm{~min}$ for the reactive dyestuff wastewater. The COD reduction of the acid dyestuff wastewater was more remarkable than that of the reactive dyestuff wastewater.

In the case of the acid dyestuff wastewater with 12.5 LPM, brown precipitation was detected up to $90 \mathrm{~min}$, but it disappeared after 120 min. The precipitation was not detected after $30 \mathrm{~min}$ at $15 \mathrm{LPM}$. In the case of the reactive dyestuff wastewater with 12.5 LPM, brown precipitation was detected at $120 \mathrm{mim}$, but it was not detected after $90 \mathrm{~min}$ at $15 \mathrm{LPM}$.

The $\mathrm{pH}$ of the acid dyestuff wastewater shifted to 7.1 after 120 $\min$ at $15 \mathrm{LPM}$. The $\mathrm{pH}$ of the reactive dyestuff wastewater shifted to 4.5 after $120 \mathrm{~min}$ at $12.5 \mathrm{LPM}$ and shifted to 4.7 after $120 \mathrm{~min}$ at $15 \mathrm{LPM}$.

\section{Decolorization}

Decolorization experiments were performed at the condition of 
remarkable COD reduction. Absorbance was measured at 400-800 $\mathrm{nm}$ wavelength with $1 \mathrm{~nm}$ resolution and every $5 \mathrm{~min}$ for $30 \mathrm{~min}$. Sample volume of $500 \mathrm{ml}$, output voltage of $12 \mathrm{kV}$, pH of 11 and oxygen flow rate of 15 LPM were fixed during the experiments.

The color of the dyestuff is mainly due to the aromatic covalent bonding [Nam et al., 1998]. Ozone is excellent in the decomposition of aromatic covalent compounds, and it is good for the decolorization of the dyestuff wastewater [Evans, 1975; Sarasa et al., 1998].

Raw dyestuff wastewater samples had dark black color. Both acid and reactive dyestuff wastewaters were decolorized remarkably with

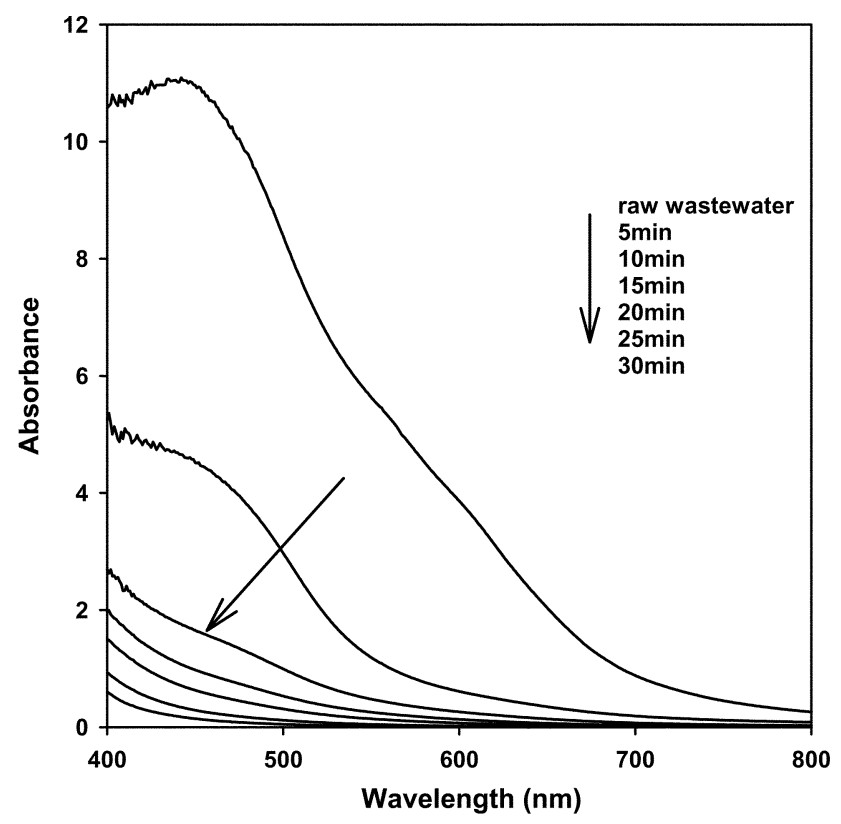

Fig. 7. The changes of the absorbance of acid dyestuff wastewater with time.

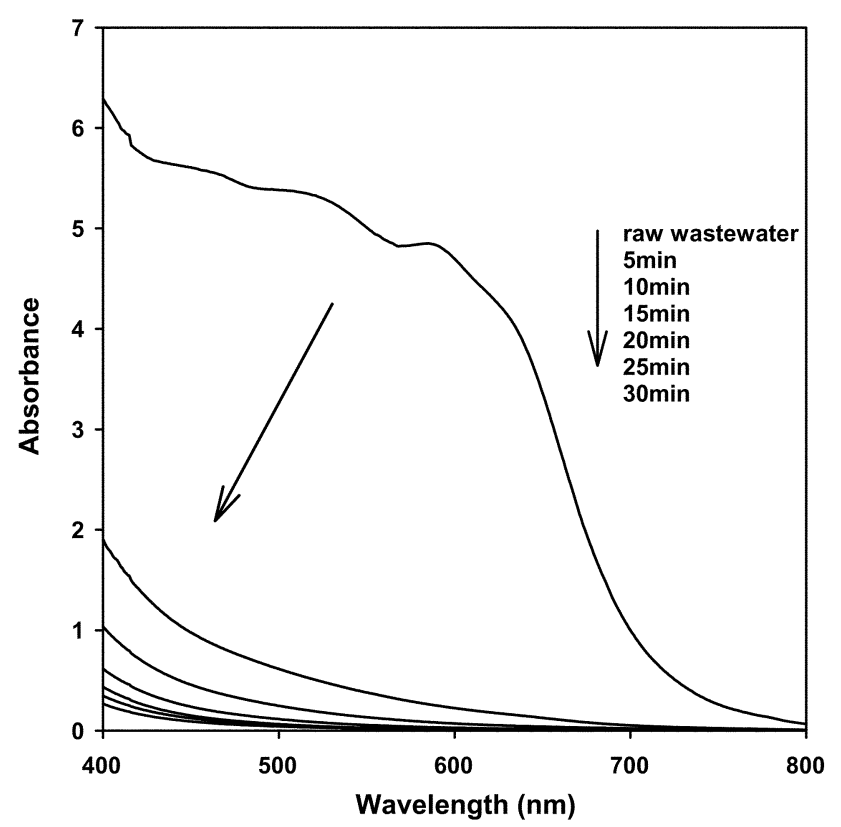

Fig. 8. The absorbance change of reactive dyestuff wastewater with time.
Table 3. Absorbance reduction of acid dyestuff wastewater (wavelength $442 \mathrm{~nm}$ )

\begin{tabular}{ccc}
\hline \hline Time (min) & Absorbance & Absorbance reduction $(\%)$ \\
\hline Raw wastewater & 11.1 & \\
5 & 4.7 & 57.9 \\
10 & 1.8 & 84.1 \\
15 & 1.1 & 90.3 \\
20 & 0.71 & 93.6 \\
25 & 0.34 & 96.9 \\
30 & 0.18 & 98.4 \\
\hline
\end{tabular}

Table 4. Absorbance reduction of reactive dyestuff wastewater (wavelength $442 \mathrm{~nm}$ )

\begin{tabular}{ccc}
\hline \hline Time (min) & Absorbance & Absorbance reduction $(\%)$ \\
\hline Raw wastewater & 6.3 & \\
5 & 1.9 & 69.8 \\
10 & 1.0 & 83.5 \\
15 & 0.62 & 90.1 \\
20 & 0.44 & 93.0 \\
25 & 0.35 & 94.4 \\
30 & 0.27 & 95.7 \\
\hline
\end{tabular}

ozone treatment. Transparent yellow color was observed after $15 \mathrm{~min}$ of reaction. Decolorization was completed in about $30 \mathrm{~min}$. The absorbance of the acid dyestuff wastewater is shown in Fig. 7 and that of the reactive dyestuff wastewater in Fig. 8. The change of the absorbance of the acid dyestuff wastewater with time at 442 $\mathrm{nm}$ is listed in Table 3, and that of the reactive dyestuff wastewater at $400 \mathrm{~nm}$ is shown in Table 4. The reduction of the absorbance of the acid dyestuff wastewater was $98.4 \%$ and that of the reactive dyestuff wastewater was $95.7 \%$ after 30 min of reaction.

\section{CONCLUSIONS}

A study of dyestuff wastewater treatment using ozone was performed. The results with the acid and the reactive dyestuff wastewater showed that COD reduction and decolorization were remarkable under the basic condition of $\mathrm{pH}$ 11. A large amount of bubbles was formed at high inlet gas flowrate. High ozone concentration was effective for the reduction of COD. Precipitation was not observed under the conditions of high COD reduction. The COD of the acid dyestuff wastewater was reduced to $95 \mathrm{mg} / \mathrm{L}$ after 90 min of reaction, and that of reactive dyestuff wastewater was reduced to $120 \mathrm{mg} / \mathrm{L}$ after $120 \mathrm{~min}$ of reaction, which satisfied the environmental discharge regulation. The $\mathrm{pH}$ was 11 , and the inlet gas flowrate was $15 \mathrm{LPM}$ with $89.3 \mathrm{~g} / \mathrm{Nm}^{3}$ of ozone concentration. After $30 \mathrm{~min}$ of ozone treatment, decolorization was completed. From these results, the ozone treatment of the dyestuff wastewater in both COD reduction and decolorization was excellent.

\section{ACKNOWLEDGMENT}

This research was funded by the National Project from the Ministry of Science and Technology. 


\section{REFERENCES}

Bigda, R. J., "Consider Fenton's Chemistry for Wastewater Treatment," Chemical Engineering Progress, 91(12), 62 (1995).

Churchley, J. H., "Ozone for Dye Waste Color Removal: Four Years Operation at Leek STW,' Ozone science \& Engineering, 20, 111 (1998).

Cooney, D. O., “Adsorption Design for Wastewater Treatment,' Lewis, Baton Rouge (1999).

Evans, F. L., "Ozone in Water and Wastewater Treatment," Ann Arbor Science, Michigan (1975).

Han, T.-S., Yoon, H.-H. and Kim, B.-S., "A Study on Coagulation and Decolorization of Acid Dye Wastewater Containing Surfactants," HWAHAK KONGHAK, 37, 482 (1999).

Hur, J. M. and Kim, S. H., "Combined Adsorption and Chemical Precipitation Process for Pretreatment or Post-Treatment of Landfill Leachate,' Korean J. Chem. Eng., 17, 433 (2000).

Ince, N. H., "Critical Effect of Hydrogen Peroxide in Photochemical Dye Degradation,' Wat. Res., 33(4), 1080 (1999).

Kang, S.-F., Liao, C.-H. and Po, S.-T., "Decolorization of Textile Wastewater by Photo-Fenton Oxidation Technology,' Chemosphere, 41, 1287 (2000).

Kim, S. H., Kim, T. W., Cho, D. L., Lee, D. H., Kim, J. C. and Moon, H., "Application of Characterization Procedure in Water and Wastewater Treatment by Adsorption,' Korean J. Chem. Eng., 19, 895 (2002).

Kong, S. H., Kwon, C. I. and Kim, M. H., "Ozone Kinetics and Diesel Decomposition by Ozonation in Groundwater,' Korean J. Chem. Eng., 20, 293 (2003).

Kuo, W. G., 'Decolorizing Dye Wastewater with Fenton's Reagent,' Wat. Res., 26(7), 881 (1992).

Lang, P. S., Ching, W. K., Willberg, D. M. and Hoffmann, M. R., "Oxidative Degradation of 2,4,6-Trinitrotoluene by Ozone in an Electrohydraulic Discharge Reactor,' Environ. Sci. Technol., 32, 3142 (1998).

Lee, C.-K., Low, K.-S. and Chung, L.-C., "Removal of Some Organic
Dyes by Hexane-Extracted Spent Bleaching Earth,' J. Chem. Tech. Biotechnol., 69, 93 (1997).

Lee, M. G. and Hano, T., "Effects of Hourly Load Variation on Treatment Characteristics in Anaerobic-Aerobic Activated Sludge Process,' Korean J. Chem. Eng., 18, 178 (2001).

Li, X. Z. and Zhao, Y. G., "Advanced Treatment of Dyeing Wastewater for Reuse," Wat. Sci. Tech., 39(10-11), 249 (1999).

Markovska, L., Meshko, V. and Noveski, V., “Adsorption of Basic Dyes in a Fixed Bed Column,' Korean J. Chem. Eng., 18, 190 (2001).

Nam, S. W., Seo, J. Y. and Lee, D. S., 'Dyestuff Chemistry,' Seongji, Seoul (1998).

Orta, M. T., Altamirano, J. M., Monje, I. and Manero, O., "Improvement of Wastewater Coagulation using Ozone,' Ozone Science \& Engineering, 20, 151 (1998).

Park, T. J., Lee, K. H., Jung, E. J. and Kim, C. W., "Removal of Refractory Organics and Color in Pigment Wastewater with Fenton Oxidation,' Wat. Sci. Tech., 39(10), 189 (1999).

Rinker, E. B., Ashour, S. S., Johnson, M. C., Kott, G. J., Rinker, R. G. and Sandall, O.C., "Kinetics of the Aqueous-phase Reaction between Ozone and 2,4,6-Trichlorophenol,' AIChE J., 45(8), 1802 (1999).

Salem, I. A. and El-Maazawi, M. S., "Kinetics and Mechanism of Color Removal of Methylene Blue with Hydrogen Peroxide Catalyzed by Some Supported Alumina Surfaces,' CHEMOSPHERE, 41, 1173 (2000).

Salem, I. A., "Kinetics and Mechanism of the Color Removal from Congo Red with Hydrogen Peroxide Catalyzed by Supported Zirconium Oxide,' Transition Metal Chemistry, 25, 599 (2000).

Sarasa, J., Roche, M. P., Ormad, M. P., Gimeno, E., Puig, A. and Ovelleiro, J. L., "Treatment of a Wastewater Resulting from Dyes Manufacturing with Ozone and Chemical Coagulation,' Wat. Res., 32(9), 2721 (1998).

Tatarko, M. and Bumpus, J. A., "Biodegradation of Congo Red by Phanerochaete Chrysosporium,' Wat. Res., 32(5), 1713 (1998).

Weber, W. J. Jr. and LeBoeuf, E. J., "Processes for Advanced Treatment of Water,' Wat. Sci. Tech., 40(4), 11 (1999). 